\title{
Building resilience beyond the EU's eastern borders. EU actorness and societal perceptions in Ukraine and Republic of Moldova
}

\author{
Loredana Maria SIMIONOV*, Gabriela Carmen PASCARIU**, \\ Nadiia BUREIKO***
}

\begin{abstract}
The resilience approach as EU's newfound paradigm places societies and communities at the heart of its interactions with external partners, and especially with its immediate neighbours. As such, in order to enhance its resilience and that of its neighbours, the EU has turned its attention from state to society, from a general top-down to a bottom-up approach. The success of this approach depends, to a certain extent, on the local trust in the EU's performance as a transformative actor. The present paper inquires how EU's actorness is being perceived beyond its eastern borders (mainly in the border regions of Ukraine and Republic of Moldova) and explores the implications for building a more resilient society in the Eastern neighbourhood. We argue that in spite of the EU's attempts to enhance its actorness in the region, or its incentives to bring about reforms and promote European values, the positive citizens' perceptions and the overall awareness of the EU still has a modest impact; this is further limiting EU's capacity to act towards building a 'stronger and more resilient society'.
\end{abstract}

Keywords: EU actorness, resilience, perceptions, society, Ukraine, Moldova

\section{Introduction}

The 2014 events in Ukraine have largely changed the security and geopolitical spectrum of the Eastern European neighbourhood, thus determining the European Union (EU) to reconsider and reshape its foreign policy agenda (Valiyeva, 2016, p.

*Loredana Maria SIMIONOV is Researcher at the Alexandru Ioan Cuza University of Iasi, Romamia; e-mail: loredana.simionov@uaic.ro.

** Gabriela Carmen PASCARIU is Professor at the Alexandru Ioan Cuza University of Iasi, Romamia; e-mail: gcpas@uaic.ro.

****Nadiia BUREIKO is Researcher at the scientific NGO “Quadrivium”, Chernivtsi, Ukraine; email: nadia.bureiko@gmail.com. 
11). Subsequently, the EU's 2016 Global Strategy (EUGS) highlighted an important paradigm shift: from a normative, liberal and optimistic view centred on diffusing European norms and values in the 2000s, to a more defensive and cautions European approach in the following decade. Consequently, EU's actions revolve around resilience as a new buzzword to explain the EU's actorness in its neighbourhood.

Since early 2000s, the concept of resilience has been central for various key documents concerning EU's development policy and agenda (Hallegatte et al., 2016; Béné et al., 2014). The per se adoption of a resilience approach in the sphere of foreign policy and external actions happened with the Joint Declaration of Riga (JDR, 2015), where societal resilience was regarded as the main objective in "strengthening the resilience of Eastern European partners faced with new challenges". Nevertheless, the EUGS (2016) endorsed resilience as a key concept in the external dimension of the European policies. Envisaged to enhance EU's own resilience and that of its partners, the EUGS introduced a more consistent and ambitious strategy, based on the concept of "principled pragmatism". Forged with this new "resilience" leitmotif, the EU's strategy was constructed more as "a middle ground between over-ambitious liberal peace-building and under-ambitious stability" (Wagner and Anholt, 2016), thus changing its modus operandi of statebuilding and transformation, from a top-down to a bottom-up approach. As such, through this newfound resilience paradigm, the EU focuses its attention, energy and actions to neighbours' societies, communities, local resources and practices. In this regard, this strong societal perspective makes the EU's resilience approach in its neighbourhood individual centric, the final goal being "functional to societal and individual wellbeing", whereas the main contributors to resilience are "individuals, with all their interactions, social ties and power structures" (JRC, 2017).

In further advancing resilience building strategies and initiatives beyond its borders, the EU should consider, on the one hand, the level of trust that societies 'on the ground' display towards the EU's capacity to perform in supporting structural reforms (Easton, 1965) and, on the other hand, the convergence between the EU's objectives and the way citizens perceive them ${ }^{1}$. Perceptions are essential in terms of societal support for the reforming processes that the EU is targeting in this region, as well as for guaranteeing the legitimacy and sustainability of its actions. Although there is consistent literature regarding the EU's actorness in its near abroad (Adolfsson, 2018; Juncos, 2016; Tocci, 2019; Wagner and Anholt, 2016), the way the citizens receiver and perceive EU's stated aims and interests in the region remain largely unexplored.

Within this context, some specific patterns are being generated within border regions (both EU and non-EU areas) considering that border effects create visible economic and social asymmetries that make the discrepancies between EU vs. non-

\footnotetext{
${ }^{1}$ More details on the relation between trust as positive perception and the public policies' effectiveness in: OECD, 2013; Bouckaert and van de Walle, 2003.
} 
EU regions more visible (Bureiko et al., 2021). Scholarship on development patterns of border regions highlights some particular associated challenges such as: lower accessibility and connectivity, institutional weaknesses, poor quality of social capital, etc. (Brown, 2017; Castanho et al., 2019). Additionally, political borders limit factors' mobility, increase transaction costs, reduce opportunities to diversify trade flows, amplify business risks, or limit the size of local markets (Geyer, 2006). However, the border regions analysed in this paper presented additional patterns, which distanced them from the classical core-periphery model, and, therefore, making for an interesting and relevant case to explore. Due to their proximity to EU's borders, these regions also benefit from various opportunities in terms of accessibility, cross-border cooperation projects or similar initiatives. In order to enhance EU's effectiveness in the border regions, the union has to ensure that local-based policies are better suited to regional particularities (both in terms of challenges and opportunities) which highlights the necessity of a bottom-up approach. To this end, an essential role belongs to the way in which the population of border regions (including those within the European Neighbourhood Policy (ENP)) perceives EU's actions (Elgström and Chaban, 2015; Schimmelfening, 2010). Against this backdrop, this paper aims at analysing EU's ability to act in these countries through a bottom-up approach, having as main priority the building and strengthening of societal resilience. The main assumption is that for enhancing EU's actorness in its eastern vicinity, the perceptions 'on the ground' need to be taken into consideration. As such, when analysing societal perceptions in the Republic of Moldova and Ukraine, the paper argues that societal resilience is significantly determined, first, by the local trust in the EU and, second, by the extent to which the local societies perceive that EU's objectives of reforms and development correspond to their own needs.

In this regard, the article is particularly relevant considering that, first, the main concept currently used by the EU to frame its external policy - resilience refers to the adaptation of individuals (Garmezy, 1971; Windle, 2011) and communities as 'layers of society' (Mitchell, 2013, p.4) and assumes 'deeper societal transformations' (Pascariu et al., 2020). Second, the analysis focuses on the border region at the Eastern flank of the EU considering that, in general, border regions are less able to react positively to shocks, and to go through transformative processes towards more resilient development models (Prokkola, 2019); however, the analysed border regions of Ukraine and Republic of Moldova seem to strongly benefit from their proximity to the EU, making them uncommon compared to regular border regions (Schimmelfening, 2008).

The first section of the paper examines the theoretical accounts on EU actorness in terms of resilience with specific focus on the Eastern Neighbourhood. The second section presents the research methods and main steps of analysis. The third section focuses on the EU's discourse regarding its external actions and policies towards its eastern borders, in order to identify the Union's main goals in the region. The fourth section explores how these goals are being perceived at societal level in 
the border regions of both Republic of Moldova and Ukraine. The final section discusses and summarizes the main findings.

\section{Theoretical account}

Generally defined as "the ability of states and societies to reform, thus withstanding and recovering from internal and external crises" (EUGS, 2016), resilience stands out as a multidimensional and multifaceted concept, being associated with keywords from various fields, such as development, security, food, policy, economic. Subsequently, EUGS represented a blend between a pragmatic approach stemming from a realistic assessment of the worsening geopolitical environment, coupled with its classical idealistic and normative approach of bettering the world. In this endeavour, in the EUGS (2016), the EU set the fostering of "state and societal resilience in the neighbourhood" as one of the five key priorities.

While the liberal paradigm promoted EU's assumed role in diffusing the liberal world order beyond its borders by targeting the transformation of the state and systems of its neighbours into a "market democracy" (Manea, 2017), the resilience one, imbued in a more pragmatic approach promoted long-term solutions to development, by targeting the transformation of the fragile societies themselves (Adolfsson, 2018). As such, the resilience approach shifted the focus from governmental institutions and elites to local actors and bottom-up actions (Juncos, 2017; Simionov, 2020; Wagner and Anholt, 2016).

The traditional community method was encouraged by the consecutive successful enlargements which has led the EU to outsource this integration logic beyond its borders. Subsequently, the recipe for successful transformation in its neighbourhood relied solely on the process of Europeanisation (Checkel, 2005; Schimmelfening, 2008). Ever since the main EU norms (democracy, good governance, freedom, rule of law, human rights, solidarity, peace, etc.) were defined and the EU's normative power was explained through its ability to generate what is considered 'normal' or 'good', the EU has promoted its norms and values outwards through enlargement policy, neighbourhood policy and its foreign policy in a broader, general sense (Incaltarau et al., 2021; Manners 2002, Schimmelfening, 2008; Smith 2010).

Resilience approach does not oppose the normative stance of EU's traditional community method, as resilience also keeps at its core the key concepts such as democracy, good governance, and the rule of law. However, there are key differentiations between the two approaches. Previously idealistic and normative with the ambition to enhance peace and wealth, the EU has accepted that crises will most probably continue to occur, thus "stability becomes the new key goal to replace the liberal peace-building" (Wagner and Anholt, 2016, p. 11). Thus, the EUGS's principled pragmatism manifested a more realistic understanding of the 
neighbourhood and shifted responsibilities from government level (be it European or neighbours' national governments) to local communities and civil societies (Juncos, 2016; Tocci, 2019). In this regard, the EU envisages the Association Agendas, which form the operational side of the Association Agreements with Moldova, Ukraine and Georgia, as avenues to achieve more resilience by offering bilateral financial and technical assistance under the European Neighbourhood Instrument (ENI) to support and fund a series of resilience building initiatives (i.e. EU4MOLDOVA, Twinning, TAIEX) (European Commission, 2020).

Furthermore, as an analytic tool of governance, resilience has overall challenged the fundamentals of top-down global governance and refocuses it on the role of "the local" and "the person" to make it more responsive to people's needs (Korosteleva and Flokhart, 2020). In this regard resilience is not only a quality of a system, but also as a way of thinking, and a process inherent to "the local that cannot be externally engineered". In order for resilience-framed governance to become more effective, the EU needs, not just to engage with 'the local' by way of externally enabling their communal capacity, but to deeply understand that resilience is a selfgoverning. (Korosteleva and Flokhart, 2020; Korosteleva, 2019; Korosteleva, 2018). Since the values, models of governance or reforms cannot be imposed from the outside, merely searching for optimal formulas at the EU level is clearly not enough. The perspective of development in the region is directly dependent on the capacity of EaP countries to assume and implement reforms "in moments of abrupt change and rupture of political and social stability" (European Commission, 2014). This means that it is necessary to find common solutions, outside and inside, and advance better understanding of the EU's partners and of the region as a whole, by integrating a deep analysis of the local community's values, behaviours.

When applied to societies and organisations, resilience acknowledges uncertainty, risks and complexity as a contemporary, constant condition, thus focusing on internal capabilities and capacities to mitigate risks and manage crisis, rather than external intervention. Subsequently, resilience highlights local agency and the need for society's responsabilisation (Juncos, 2016) and changes EU's role from a supreme protector of liberal values to a facilitator of local solutions to local problems (Bourbeau, 2013). However, EU's actions must be differentiated, not only at national level, but also at regional ones. This demand arises due to spatial differences in terms of regions' responses to economic shocks and their ability to adapt to new economic circumstances (depending on the geographical positioning of a region); moreover, border regions tend to be less resilient to economic crisis, to environmental, social or political shocks.

Within this context, perceptions on the ground become pinnacle for EU's transformation strategy through societal resilience in EaP countries. Societal resilience builds on strong social capital (Ledogar and Fleming, 2008) and implies civic engagement, cooperation and collective action, social networks, shared identity and shared norms, trust in institutions (Bernier and Meinzen-Dick, 2020; Putnam, 
1995). Trust in the EU capacity to transform its near abroad is critical in social capital building and is correlated with the positive perceptions of citizens on the EU's role in their country or region (Elgstrom and Chaban, 2015). This way, EU's actions should revolve around allowing the societies on the ground - "the local" an opportunity to grow their own critical infrastructures and collective agency, in their pursuit of 'good life' (Korosteleva, 2018), but also around a strong social capital (Aldrich, 2017).

Consequently, in the following section the paper inquires how the EU is perceived in the two eastern neighbourhood countries and whether there is a correspondence between the EU's official objectives in the neighbourhood and the local societal perceptions in the region.

\section{Methodology}

The paper is based on mixed method research (discourse and content analysis on the one hand and population survey on the other hand) that is determined by our assumption and arguments.

Discourse analysis (DA) is used to identify the main objectives and priorities that the EU sets in its near-abroad as well as to understand how the resilience concept has been used when framing EU's external policies. The DA is particularly relevant to the aim of the paper since this method is often employed in the field of international relations and diplomacy studies, particularly pertinent for the case of the European Union (Petrova and Delcour, 2020; Wagner and Anholt, 2016). Considering that the $\mathrm{EU}$, as an international actor, has been evolved through various linguistic and textual representations (i.e. treaties, summits, councils, institutions, bureaucracies etc.), "in addition to the acquis communautaire and the acquis politique, the third pillar of the European edifice is certainly the acquis linguistique". This is particularly relevant for the EU's external affairs, "where the development of foreign policy documents (...) can therefore match the actual policy towards relevant regions or even amount to such a policy" (Haukkala and Medvedev, 2001, pp. 13-14).

The DA draws on the text corpus that includes all official documents issued by the European Commission and Council available on the EU's External Action Service official website for a timeframe of ten years, 2009-2019. This timeframe was chosen for the analysis taking into account, first and foremost, the launching of the Eastern Partnership in 2009, followed by the variety of events which have challenged the European community over the last decade (terrorist attacks, refugee crisis, annexation of Crimea and subsequent war in Donbas etc.). As such, the DA of this corpus and within this particular timeframe has helped us identify how the EU frames and perceives its relations with eastern neighbours and provide a better understanding of the self-prescribed role that the EU envisages in the neighbourhood. Additionally, in order to validate the findings of the conducted DA, we have employed content analysis (CA) on the entire corpus. The CA was 
conducted with Atlas.ti software and has helped us identify the most frequently used words/concepts, as well as to triangulate the main narratives within EU's discourse (through coding) to further substantiate and validate the findings.

Since scholars on the EU external policy have largely highlighted the relevance of external societal perceptions of the EU (Abrahams, 2013; Bachmann, 2013; Bretherton and Vogler, 2006; 2005; Chaban et al., 2013; Elgström and Chaban 2015; Holland and Chaban, 2014; Lucarelli, 2013; Hill, 1993), employing the survey method, this research further explores how the EU's goals and objectives identified during DA are perceived at the societal level in both Republic of Moldova and Ukraine and whether there is a congruence between the EU priorities and the societal preferences.

To this aim, the paper centralizes the findings of the two questionnaire-based surveys simultaneously conducted in those regions of Ukraine $(\mathrm{N}=400)$ and Republic of Moldova $(\mathrm{N}=415)$ which have a direct border with the EU. Mainly, the two surveys were conducted in Chernivtsi, Ivano-Frankivsk, Lviv, Tranacarpathian, Volyn' regions (oblasts) in Ukraine and all the regions in Republic of Moldova, taking into account that EU's cross-border cooperation (CBC) programmes consider all the regions of Republic of Moldova as border ones. We have chosen this method since, first, surveys are reasonably straightforward in the way they tap into the societal perceptions and, second, surveys are more preferable when a larger pool of respondents is being desired (Gideon, 2012). Both surveys considered the age, gender, urban/rural distribution of the population. The questionnaire was identical for both Ukraine and Republic of Moldova, constructed in English, then translated into the national languages and applied by two contracted companies in September 2019. The questionnaire inquired to which extent the population from the region is familiar with the EU and its role, what attitudinal trends and general feelings vis-àvis the EU prevail, how positive the population is in the perceptions of the EU, etc.

\section{EU's resilience discourse in the Eastern neighbourhood and relevance for the immediate border regions}

A linear reading of the entire corpus immediately reveals that resilience represents the main narrative of EU's foreign policy agenda. The prevalence of the resilience narrative is also validated by the content analysis considering that word frequencies singled out resilience as a keyword when it comes to EU's current discourse regarding its foreign policy and agenda, thus showing up 1079 times across its main official documents of EU's External Action Service. Initially adopted as a key objective and priority for tackling issues within EU's development agenda (Hallegatte et al., 2016; Béné et al., 2014), the resilience concept has also inevitably 'contaminated' both internal and external agenda, with specific relevance for border regions. Based on the principle of "living up consistently to our values internally will determine our external credibility and influence" (EUGS, 2016, p. 15), the concept 
has been adopted from EU's internal policies and infused in its external actions of "peace-building and the resilience of States and societies, in and around Europe." (EUGS, 2016, p. 4).

The overall goals and instruments of EU in its Eastern Neighbourhood are intrinsically linked to its overall foreign policy, but also to its internal objectives (mainly, the cohesion and the sustainable development) in an integrative perspective. In terms of resilience, European Commission (European Commission, 2012; 2013; $2018 \mathrm{a}$; 2018b) proposes a multifaceted approach, with a broad range of referent objects, spanning across a variety of policy areas, given that:

[...] multi-facetted aspects of resilience building, actions must be sustainable, multi-sectoral, multi-level, multi-partner and strategically and jointly planned by the people affected or at risk, communities, governments (at the local, subnational and national levels) and civil society (European Commission, 2013).

In the JDR (2015), the EU outlines as main objective the fostering of societal resilience, with the aim of "strengthening the resilience of Eastern European partners faced with new challenges". However, the endorsement of resilience as a key priority of EU's external agenda occurred in 2016 EUGS, where throughout the text, the concept showed up 41 times, linked to a diverse set of directions and priorities, revolving around democracies, state, society, economy, and environment.

The analysis of EU's discourse regarding resilience in the neighbourhood countries indicated the existence of six main narratives with society and communities ranking the fourth (Figure 1). In most of the official documents addressing the Eastern Neighbourhood (JOIN, 2017; EUGS, 2016; JOIN, 2013) the discourse insists on the fact that societal resilience is equally important as security, considering all the intrinsic notions that societal resilience entails, such as strong civil societies, human rights, political participation and sustainable development.

If we break down the analysed period in two, having the 2016 EUGS as the breaking point, the corpus analysis outlines indeed that the EUGS represents the moment of a clear paradigm shift in EU's external policy. The period predating the EUGS highlights a top down approach, thus having the formal institutions above the society. As such, the EU's declared goals in the region through its Eastern Partnership initiative are built upon four pillars, as follows: Stronger Economy (economic development and market opportunities); Stronger Governance (strengthening institutions and good governance); Stronger Connectivity (connectivity, energy efficiency, environment and climate change); and Stronger Society (mobility and people-to-people contacts) (JDR, 2015). Although the fourth pillar refers to society, the means to engage it also send to a top-down approach. For instance, in 2011, the EU sets four aims as "a new response to a changing Neighbourhood" in which the societal engagement is left behind on a secondary level (European Commission, 2011). Overall, the EU's declared aims towards EU's Eastern neighbours indicated a focus on a top-down approach in all spheres involved, 
be them political, economic or societal. As such, the most frequently observed objectives revolve around regional development, institutional capacity-building and diversification of the economy pointing towards a general liberal approach. A closer look at the objectives signals a need of a place-sensitive approach for the border regions in the pre-configuration of resilience capacity building. In this sense, the EU's aim of strengthening the resilience of these regions and promoting sustainable development requires specific bottom-up approaches that are based on the local population' vision and potential for social resilience building.

\section{Figure 1. Thematic reference fields of EU's external actions \& resilience discourse}

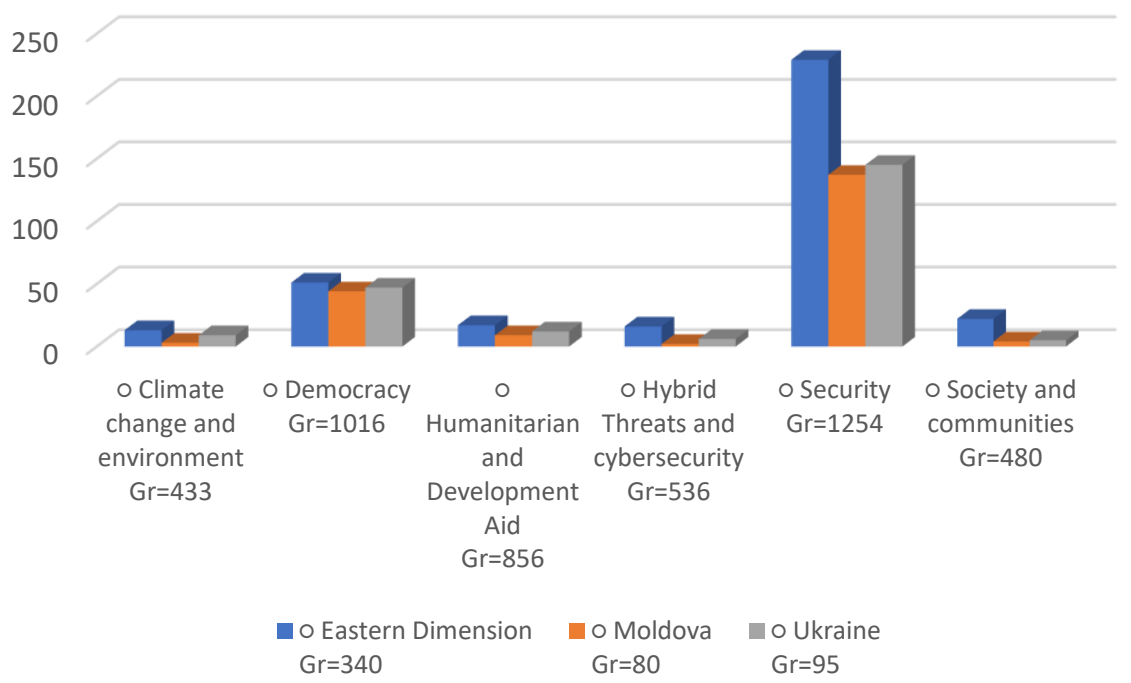

Source: Authors' representation using Atlas.ti

Within the second timeframe that followed the 2016 EUGS the discourse is imbued with resilience-based goals and objectives that shape the overall EU's external actions. The EU's strategic adoption of resilience aims at achieving and sustaining the ambitious set of objectives for the EU's external action of statebuilding and transformation through a bottom-up approach with the focus on societal life via strengthening, among others, 'the adaptability of (...) societies, communities and individuals to political, economic, environmental, demographic or societal pressures' as well as 'the capacity of societies, communities and individuals to manage opportunities and risks in a peaceful and stable manner' (European Commission, 2017). Throughout the corpus, there could be identified a certain emphasising on resilient societies as featuring democracy, trust in institutions and 
sustainable development. Through the "many ways to build inclusive prosperous and secure societies" (EUGS, 2016, pp. 25-26), the EU's discourse focuses on empowerment, responsibility, creativity, local resources and self-awareness, all elements that are in line with EU's resilience-based paradigm. Although the general objectives still revolve around security, regional development, institutional capacitybuilding and economic diversification, they all appear to include elements that combine both liberal and resilience-based approaches. As such, the broad range of aims and objectives target not only the formal institutions, but also the citizens and vulnerable groups. The analysis of the two periods before and after the EUGS indicates a certain paradigm shift, away from the liberal approach, by introducing a strong societal dimension, thus keeping however a great focus on institutional development. As such, through its discourse, the goals and aims for the countries bordering the EU are clearly stated. However, in order to reach these goals, the expected impact on the societies 'on the ground' should be considered; the EU has also to make sure that its voice is being heard and properly perceived, as well as to ensure that its objectives in the neighbourhood meet the societal expectations and the level of local trust.

\section{Perceptions of EU's actorness in the border regions of Ukraine and Republic of Moldova}

After proclaiming its independence, both Ukraine and Republic of Moldova have been long vacillating between the European community and Russia (Bureiko and Moga, 2018; Całus and Kosienkowski, 2018; Samokhvalov, 2015; Korosteleva, 2010). In spite of significant political and economic pressure from Moscow, Ukraine and Republic of Moldova have officially embarked the EU integration project in 2014 when they both signed the Association Agreements (AA). Together with the key provisions for a Deep and Comprehensive Free Trade Area, the AA stipulates stronger political and economic ties, modernisation of economy, harmonisation of laws, respect for common values and accession to various EU-funded programmes. Whilst the AA is based upon a strict conditionality approach, the EU is deeply committed to support the reform agenda and contribute to modernisation efforts of both countries. Republic of Moldova (in 2014) and Ukraine (in 2017) have obtained the visa-liberalization regime that transferred them both to the list of countries whose citizens no longer require visa obligation while travelling to the Schengen area. This facility has provided mobility for the Ukrainians and Moldovans, which has contributed to increased fluxes of inward EU-travelling and cross-border transit (European Migration Network 2019). However, for the EU to consolidate societal resilience beyond its borders, there is a need of a certain level of societal positive perceptions and expectations regarding the EU's role and actions in the region. Therefore, we further analyse the societal perceptions of the EU, as well as the 
relevance of the EU's proposed objectives in relation to societal needs and preferences.

\subsection{General awareness, attitudes and feelings concerning the EU}

In the border regions of both Ukraine and Republic of Moldova, all respondents confirmed that they had heard about the European Union ${ }^{2} .89 .4 \%$ of respondents from Ukraine and $88.9 \%$ of respondents from Republic of Moldova are interested in receiving updates on the relations their country has with the EU and the way how these relations are evolving. However, the level of awareness of the EU is reported as generally low. Accordingly, 56.9\% of respondents from Ukraine and $76.9 \%$ of respondents from Republic of Moldova agree and somewhat agree that people in their countries have limited information about the EU (Figure 2). This could be partially be explained by the fact that people from both countries do not often have first-hand information of what the EU stands for since they still rarely visit the EU states or did not have the chance to visit them at all. For instance, 56.5\% of respondents from Ukraine and $37.1 \%$ of respondents from Republic of Moldova have never visited any of the EU member states during the last ten years. $33.1 \%$ respondents from Ukraine and $41.7 \%$ respondents from Republic of Moldova have visited the EU only up to 5 times during the last ten years, usually travelling to the bordering EU state, situated closest to the place of their own residence. Hence, personal reflections and general attitudinal trends concerning the EU appear to be mostly determined by media. In both countries, television has been reported as the main source of information about political, economic, cultural or ecological developments in the EU.

Limited possibilities to obtain more knowledge about the EU could challenge building societal trust in the EU actorness. Additionally, the low-level of crossborder migration reduce possibilities to build social networks, to sufficiently promote cross-border cooperation and collective actions as key elements of societal resilience. While being asked how many member-states the EU has, only $33.4 \%$ of respondents from Ukraine and $24.1 \%$ from Republic of Moldova knew the answer. In Ukraine the younger generations (age groups 18-29 and 30-39) appeared slightly more knowledgeable about the EU compared to older citizens, whereas in Republic of Moldova the most knowledgeable segment of population is the age group 40-49. In both countries there is a direct correlation between knowledge of the EU and the level of respondents' education - the higher educational level a respondent has, the more knowledgeable he/she is about the EU.

\footnotetext{
${ }^{2}$ Hereinafter, referring to Ukraine/Republic of Moldova we mean only those regions of both countries, which border with the EU.
} 


\section{Figure 2. To which extent do you agree that people in your country have limited information about the $\mathrm{EU}$}

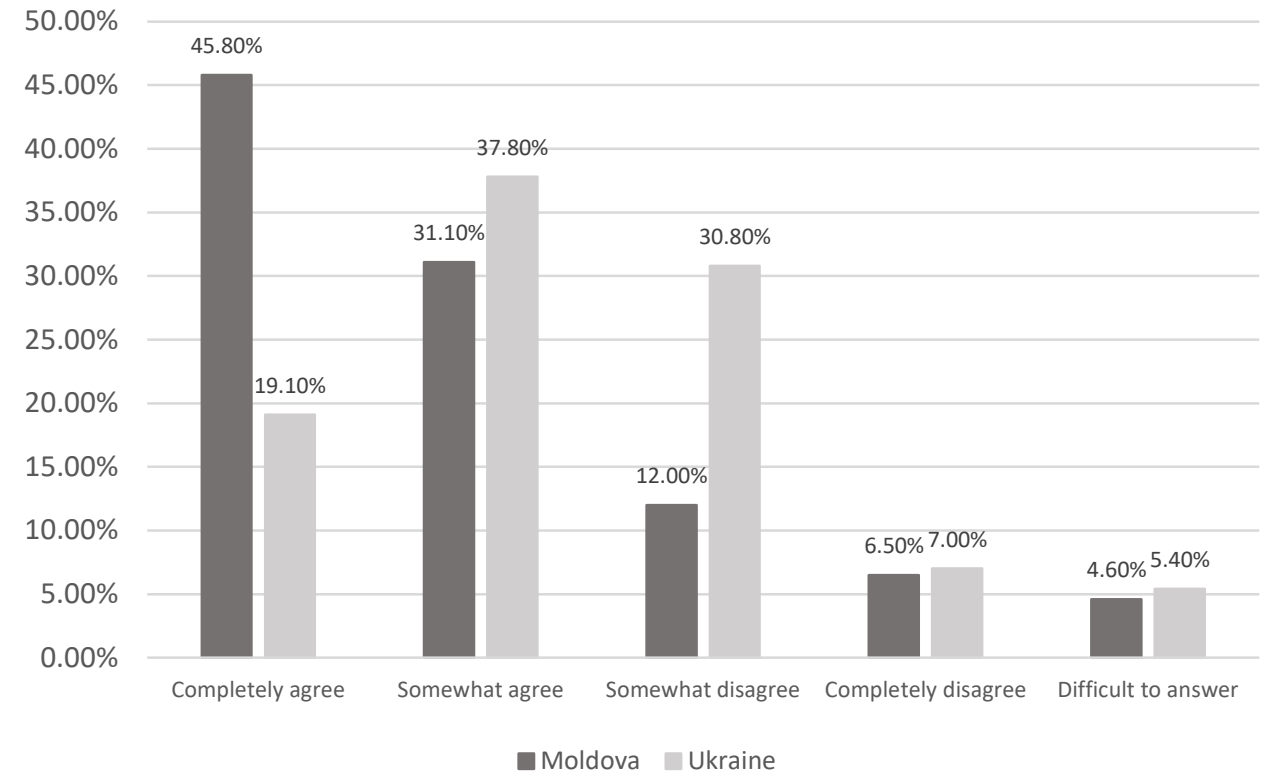

Source: Authors' representation based on the survey data

The survey data revealed not only the general level of knowledge about the EU actorness in the analysed regions, but also showed awareness of the intervention framework defined by the Eastern Partnership and cross-border cooperation projects as specific tools for border regions. Thus, in Ukraine, there is limited knowledge about the projects supported and financed by the EU at the level of the locality (namely, village, town, city) and at the level of the region, despite the fact that the regions where the survey was conducted are subjects to cross-border cooperation projects, as we have previously mentioned (Figure 3). As such, only $12.7 \%$ and $16.1 \%$ have heard about the existence of such projects accordingly. In Republic of Moldova, the awareness of such initiatives implemented with the EU's support is somewhat higher, at $34.2 \%$ and $25.8 \%$, respectively. The overall awareness is higher when it goes to the visibility of the nation-wide projects - in Ukraine, 50.5\% of respondents know about the EU-funded projects in various domains. In Republic of Moldova, the level of awareness is even higher, at $72.8 \%$ Yet, the Eastern Partnership has registered a low level of visibility. Only $33.4 \%$ of respondents from Ukraine and $17.6 \%$ of respondents from Republic of Moldova know about the existence of this framework of cooperation between the EU and the eastern neighbouring countries. Subsequently, the majority of the population in both 
countries agrees or rather agrees that the EU has a limited presence in their country $-60.5 \%$ in Ukraine and $68.9 \%$ in Republic of Moldova.

Figure 3. Have you ever heard of any project funded by the EU in your locality, region, country: positive answers

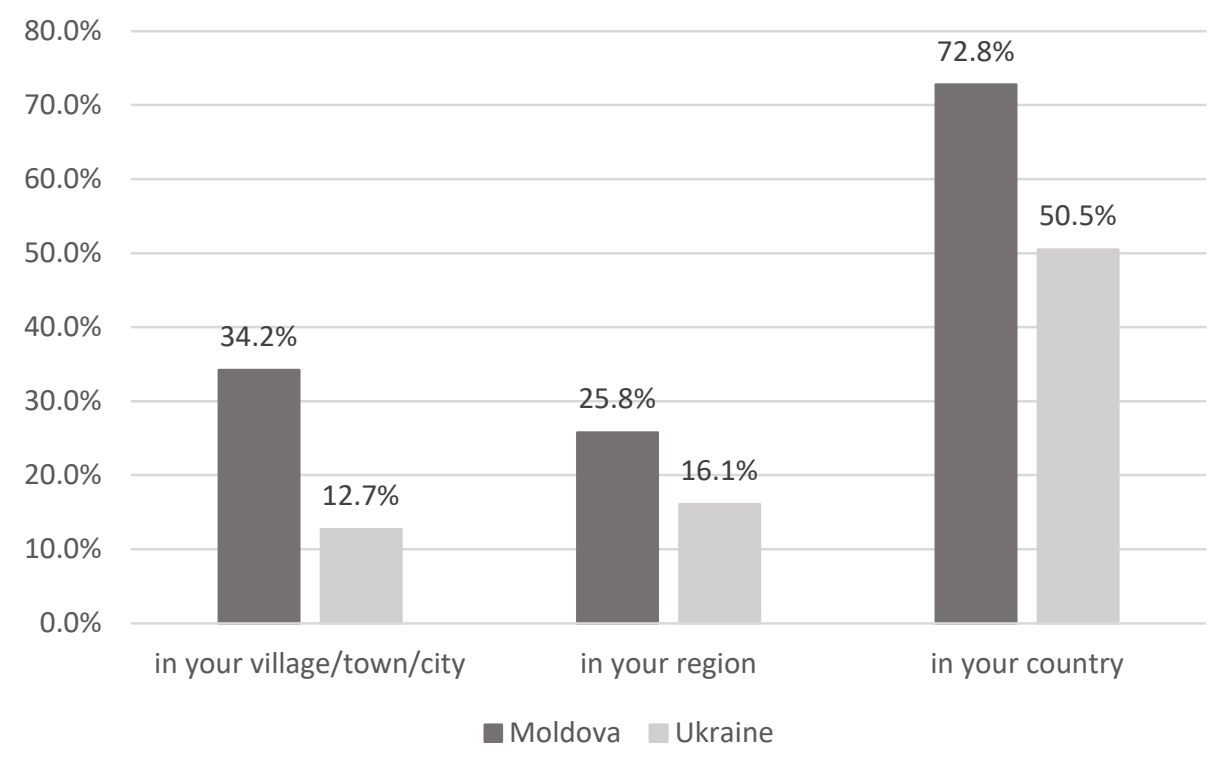

Source: Authors' representation based on the survey data

Such results suggest that the EU's capacity to address society in the region is still modest that shows inefficient communication strategies regardless of the EU's increased interest in understanding the key role of communication in enhancing knowledge and strengthening trust in the EU (European Commission, 2013) needed for a stronger and more resilient society as a key EU's objective in the eastern borderlands.

However, in spite of the rather modest awareness of the EU-driven initiatives in the region indicated by the population from both Ukraine and Republic of Moldova, positive attitudinal trends vis-à-vis the EU prevail that is critical for building societal trust in the EU's actorness. Thus, the EU's image is generally being associated with positive narratives of being 'good' and 'friendly' as well as 'reliable' and 'important' partner (Figure 4). 


\section{Figure 4. Societal attitudinal trends towards the EU}
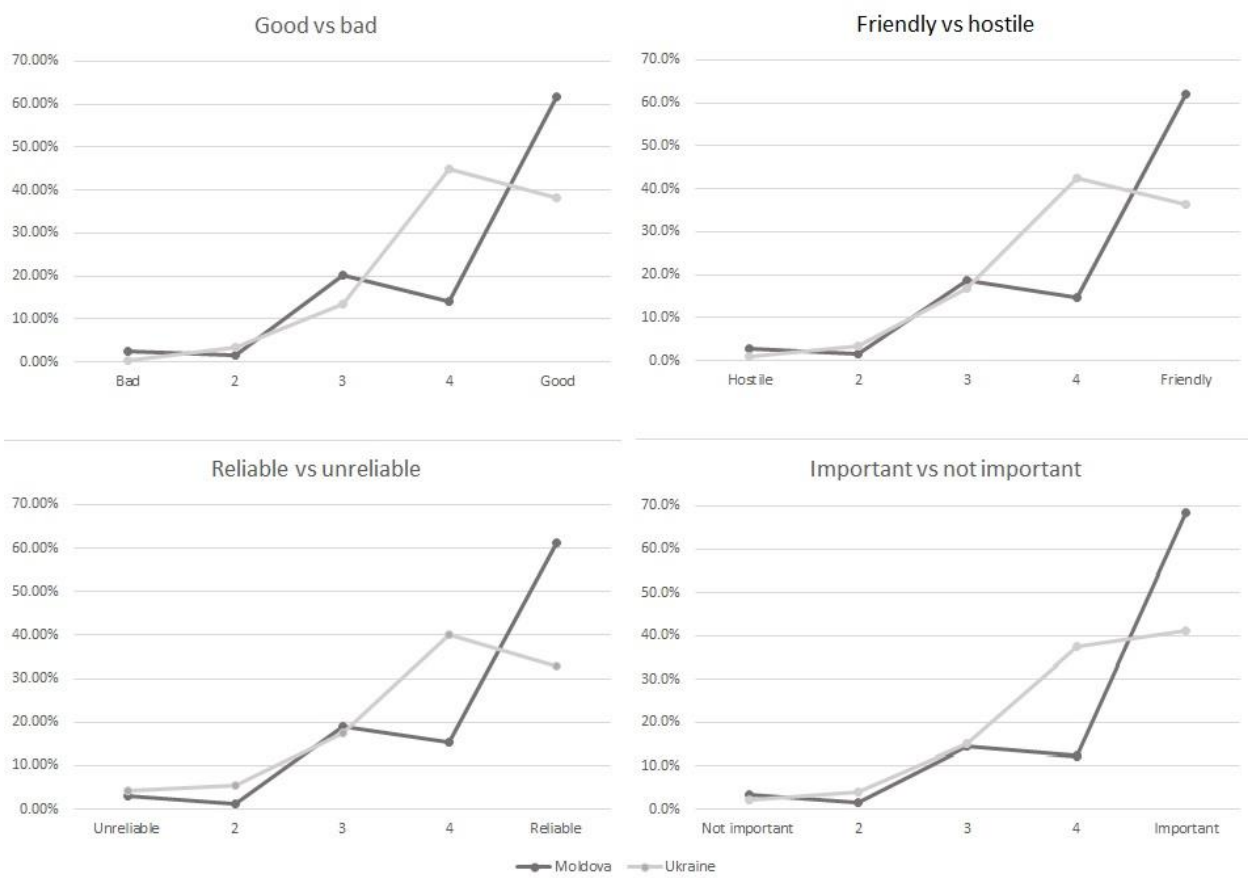

Source: authors' representation based on the survey data

In particular, in both countries references to the EU generate enthusiasm and hope rather than indifference, anxiety, mistrust or alienation (Figure 5).

\section{Figure 5. Overall feelings concerning the EU}

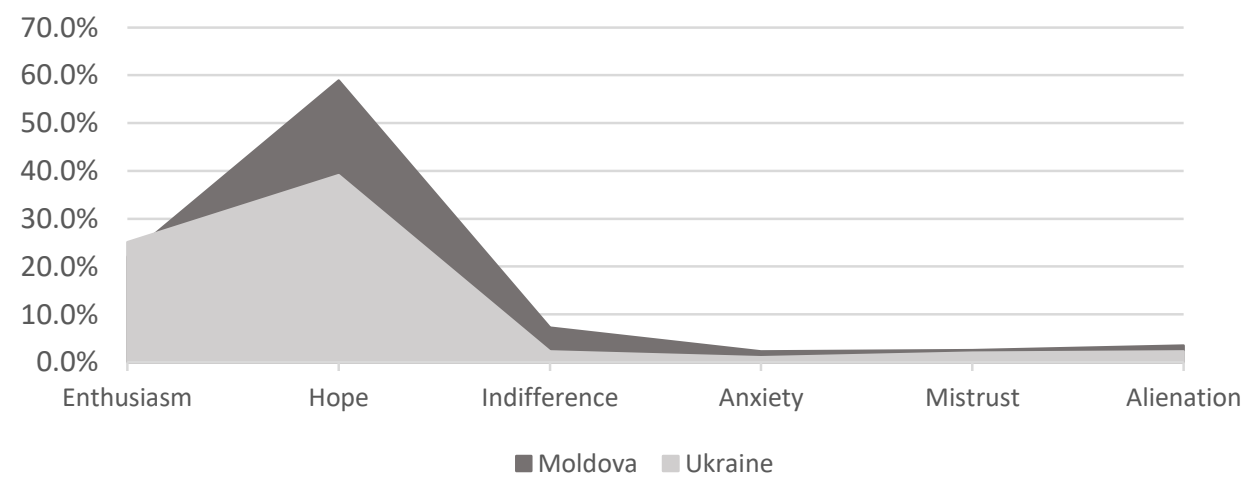

Source: authors' representation based on the survey data 
Although there are some differences in public perceptions from the two countries, the EU is generally positively seen in both of them and the capital of trust the EU has in the border regions of Ukraine and the Republic of Moldova could contribute to strengthening the EU's capacity for action from a bottom-up approach.

\subsection{Perceptions and expectations of EU's actorness}

In the analysed regions of both Ukraine and Republic of Moldova, the EU is mostly associated with democracy $66.6 \%$ in Ukraine and $71.6 \%$ in Republic of Moldova) and market economy (56.2\% in Ukraine and $68.4 \%$ in Republic of Moldova). For Republic of Moldova, the other important values linked to the EU's image are solidarity (68.2\%), security (68\%), human rights $(67.7 \%)$, health and social protection (67.7\%). In Ukraine, the respondents ranked the following EUdriven values as important: human rights $(55.5 \%)$, economic prosperity $(53.2 \%)$, health and social protection (50.8\%), whereas the percentages for solidarity (38.5\%) and security (35.5\%) are slightly lacking behind the ones indicated in Republic of Moldova. This might be explained by the EU's modest role and limited actions to contribute more efficiently to the current security crisis in Ukraine.

In both countries, the majority of respondents believes or somewhat believes that the EU is positively perceived by their people (83.9\% in Ukraine and $78.3 \%$ in Republic of Moldova), that both Ukraine and Republic of Moldova share many common values with the EU (74.2\% in Ukraine and $72.3 \%$ in Republic of Moldova) and, moreover, have the EU as a model for further development (79\% in Ukraine and $87.9 \%$ in Republic of Moldova). Particularly, Ukrainians and Moldovans from the border regions see the EU as a positive example of economic development, human rights and freedom of speech and find the EU's support very important for advancing reforms in their countries. This shows the attractiveness of the EU's model as it is perceived by the respondents. The majority of respondents have emphasized the important or somewhat important role the EU plays to support the economic development of Ukraine and Republic of Moldova (87\% of respondents from Ukraine and $87.7 \%$ of respondents from Republic of Moldova) and the significance of the EU's investments (86\% of respondents from Ukraine and 83.1\% of respondents from Republic of Moldova).

Overall, economic and trade cooperation were indicated as the most developed fields of cooperation between the EU and the neighbouring countries, followed by cross-border cooperation and academic exchanges (Figure 6). 76.9\% respondents from Ukraine and $84.8 \%$ respondents from Republic of Moldova are aware that the EU provides their countries with financial assistance for cross-border cooperation programmes. However, in the mentioned regions, which are subjects to and the main beneficiaries from the EU's cross-border cooperation programmes, only $32.4 \%$ of respondents in Ukraine and $21.9 \%$ of respondents in Republic of Moldova see cross-border cooperation as an actively developing area. 
Figure 6. What types of cooperation are mostly developing between the EU and your country today?

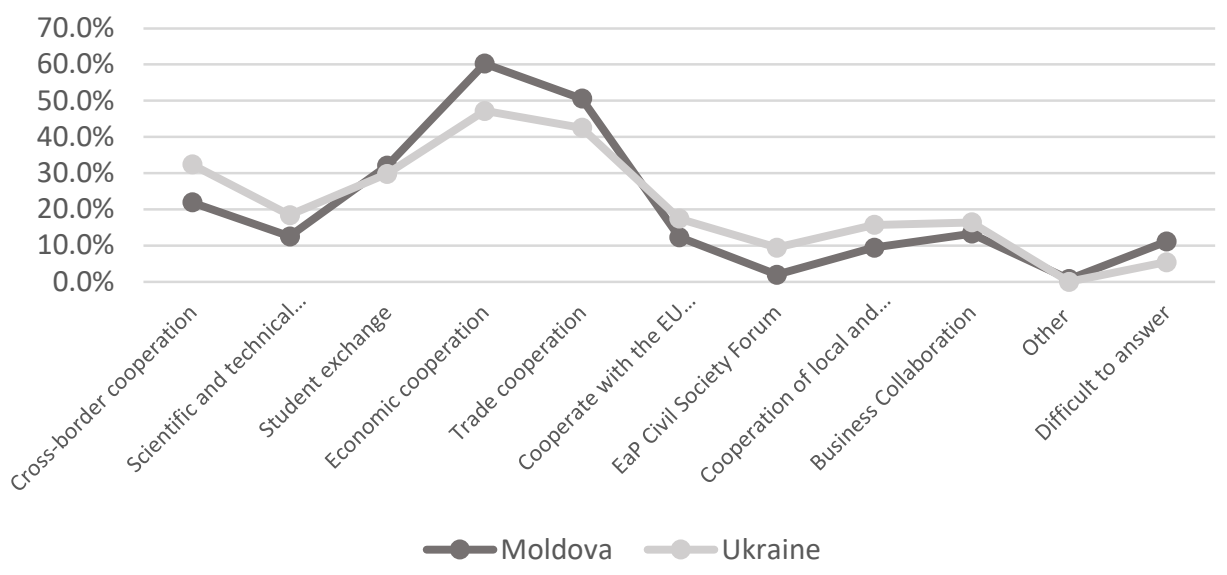

Source: authors' representation based on the survey data

When assessing the relations between their country and the EU, the majority of respondents consider them as positive. $86.7 \%$ of respondents from Ukraine and $89.9 \%$ of respondents from Republic of Moldova rank these relations as good or somewhat good. However, they $64.5 \%$ of respondents from Ukraine and $76.4 \%$ of respondents from Republic of Moldova still believe that their countries should cooperate more actively, while $26.1 \%$ and $15.9 \%$ are entirely satisfied with the current pace of cooperation. Compared to 2009, the year when both Ukraine and Republic of Moldova joined the Eastern Partnership, the present-day dynamic of the relations with the EU has been mostly perceived as improving (53.8\% in Ukraine and $58.1 \%$ in Republic of Moldova). Concurrently, 31.8\% of respondents from Ukraine and $30.6 \%$ of respondents from Republic of Moldova believe that the relations with the EU have not changed much since 2009 despite their countries have significantly progressed with the European integration, especially after the Association Agreement with the EU was signed. Overall, our findings suggest a societal request for closer cooperation between their countries and the EU that highlights a promising potential to further develop social networks, collective actions, civic engagement and shared norms as elements of a resilient society.

\section{Conclusions}

In order to better grasp the public perceptions vis-à-vis the EU, the paper focused on the two cases of Ukraine and Republic of Moldova, considering their location at the EU's immediate eastern border, as well as their willingness to further 
develop closer ties with the EU (for instance, by singing the AAs). With the focus on those specific regions of Ukraine and the Republic of Moldova which have a direct border with the EU, this paper investigated the local public trust in the EU, as one of the critical points in building societal resilience. The research combined a discourse analysis and a survey that have helped to understand whether the EU resilience approach and development priorities in the border regions are congruent with the local societal perceptions and expectations. According to the survey data, at the level of societal perceptions, both in Ukraine and Republic of Moldova, the general interest about the EU is high, whereas the positive attitudes towards the EU prevail. People tend to believe their countries share many common values with the EU and see the EU as a model for development, which represents an overall favourable context to enhance EU's contribution to build resilient societies beyond its borders. In this context, the EU is mostly associated with democracy and market economy and is seen as an example of economic development, human rights protection and freedom of speech. However, the overall awareness of the EU is still lagging behind given that the respondents declared not to have sufficient information and knowledge on EU-related matters. In addition, despite of various instruments and tools the EU employs to enhance the European agenda in the two mentioned countries, the majority of respondents believe that the EU still has a limited presence in their countries. Moreover, the awareness of EaP initiative as framework of cooperation between the EU and the eastern neighbouring countries has been also reported as low.

Such findings show that regardless of beneficiating from a relevant trust capital in both countries, EU and its actions in border regions are insufficiently known. The knowledge of what the EU is and does is relatively low in both countries, that could limit conditions for stronger and more resilient society building. Moreover, the priorities and programs implemented by the EU are not always in line with the societal expectations. In the general architecture of external relations with its eastern neighbours, the Union has not paid enough attention to the structural needs and expectations of its partners, especially before the paradigm shift, by simply associating the neighbours' interests in development reforms and international opening with the desire to suddenly replicate and transform into a European model of development (Simionov and Tiganasu, 2018). In this context, the EU should focus more proactively on societies in the region. Subsequently, such an approach could contribute to a better efficiency of the dialogue and strategic communication between the EU and its neighbours, as a prerequisite for promoting prosperity, stability and security in the region.

Despite of the fact that the survey was conducted in the regions directly bordering the EU which are subjects to a variety of EU funded cross-border cooperation $(\mathrm{CBC})$ programmes (designed to enhance $\mathrm{CBC}$ between the EU and Ukraine/Republic of Moldova), direct and consistent CBC projects are yet to be seen, as they are currently modest. Furthermore, the level of information about projects 
supported and financed by the EU at local and regional levels is very low, both in Ukraine and the Republic of Moldova. However, at national level the visibility of the EU-funded project is much higher in both countries. Such findings signal the need to enhance the communication strategy at local and regional levels.

In this endeavour, the EU should direct its energy into strengthening mobility programs, not only for educational purposes but also for the general population through various people-to-people projects, both through CBC programs and other similar initiatives. This would lead to a better knowledge of the EU and an increase in the attractiveness of its values, principles and development model and also to an increased interest in CBC programs as one of the key tools for the EU to strengthen its resilience and that of its neighbours. The EU should orient its funding towards strengthening communication, sharing information and enhancing visibility through $\mathrm{CBC}$ tools and programs.

In lines with its stated goals in the near abroad - that of enhancing societal resilience, the survey findings point out the need for additional investments in human capital development in the Eastern Neighbourhood countries. In this regard, the EU should also focus on increasing the role of additional cooperation networks - such as Jean Monnet or Europe Direct, which can contribute to providing information to the general public and increase the visibility of EU's actions in the region, of its contribution to the development of the economies and societies of the neighbouring countries.

As such, for the purpose of enhancing societal resilience in its near-abroad, the EU has to make sure that its voice is being heard; As such, the EU has needs to ensure that societies 'on the ground' are aware of its intentions and are willing to undergo the envisaged transformation. Otherwise, the EU will not succeed (despite its specific interests and efforts of Europeanisation encompassed in its Neighbourhood Policy agenda) to reduce the border effects of various physical, administrative, economic, cultural, institutional or political barriers nor to considerably reduce the risks of a growing instability at its eastern borders so that it avoids the deepening of new dividing lines in Eastern Europe. CBC programs could play an important role in this context, but they must be built on an in-depth knowledge of society and on the manner in which people in these regions envisage development prospects. The raising awareness within the European neighbourhood policy of such a conditionality paved the way for the EU's resilience approach.

Acknowledgement: This research has been conducted within the Jean Monnet Network: project 2017-2625 'European Union and its Neighbourhood. Network for Enhancing EU's Actorness in the Eastern Borderlands (ENACTED). 


\section{References}

Abrahams, N. (2013), Euroscapes in Senegal seen through the lense of the hip hop movement, L'Espace Politique, 19(1), pp. 2-18.

Adolfsson, T. (2018), The Rise of Resilience in EU Foreign Policy - A shift of Paradigm or Parlance? (retrieved from https://www.divaportal.org/smash/ record.jsf?pid=diva2\%3A1284564\&dswid=187).

Aldrich, D.P. (2017), Rethinking Resilience, Adaptation and Transformation in a Time of Change, in: Rethinking resilience, adaptation and transformation in a time of change, pp. 357-364, Springer, Cham.

Bachmann, V. (2013), The EU as a geopolitical and development actor: views from East Africa, L'Espace Politique, 19(1), pp. 2-22. https://doi.org/10.4000/espacepolitique.2561

Béné, C., Newsham, A., Davies, M., Ulrichs, M. and Godfrey-Wood, R. (2014), Resilience, Poverty and Development, International Development, 26(5), pp. 598-623.

Bernier, Q.R. and Meinzen-Dick, R. (2014), Resilience and Social Capital (retrieved from https://reliefweb.int/sites/reliefweb.int/files/resources/2020resilienceconfpaper04.pdf).

Bouckaert, G. and S. van de Walle, S. (2003), "Comparing measures of citizen trust and user satisfaction as indicators of 'good governance': Difficulties in linking trust and satisfaction indicators", International Review of Administrative Sciences, 69(3), pp. 329-344. https://doi.org/10.1177/0020852303693003

Bourbeau, P. (2013), Resiliencism - Premises and Promises, Securitization Research, Resilience: International Politics, Practices, and Discourses, 10, pp. 3-17. https://doi.org/10.1080/21693293.2013.765738

Bretherton, C. and Vogler, J. (2005), The European Union as a global actor, London: Taylor and Francis. https://doi.org/10.4324/9780203022672

Brown, W. (2017), Border barriers as sovereign swords: Rethinking walled states in light of the EU migrant and fiscal crises, Political Geography, 59(C), pp. 1-10. https://doi.org/10.1016/j.polgeo.2017.02.006

Bureiko, N. and Moga, T.L. (2018), “Bounded Europeanisation': the case of Ukraine' in: P. Flenley, P. and Mannin, M. (Eds.), The European Union and its eastern neighbourhood. Europeanisation and its twenty-first-century contradictions, pp. 71-85, Manchester: Manchester University Press. $\underline{\text { https://doi.org/10.7765/ }}$ $\underline{9781526109118.00015}$

Bureiko, N., Moga, T.L., Gheorghiu, A. and Ibănescu, B.-C. (2021), Between the Home and Kin-State: Self-Identification and Attachment of Ukrainians and Romanians in the Ukrainian-Romanian Borderland of Bukovina, Problems of Post-Communism, 68(1), pp. 53-65. https://doi.org/10.1080/10758216.2020.1734470

Całus, K. and Kosienkowski, M. (2018), 'Relations between Moldova and the European Union' in: Flenley, P. and Mannin, M. (Eds.), The European Union and its eastern neighbourhood. Europeanisation and its twenty-first-century contradictions, pp. 99114, Manchester: Manchester University Press. https://doi.org/10.7765/ $\underline{9781526109118.00017}$ 
Castanho, R.A., Vulevic, A., Naranjo Gómez, J.M., Cabezas, J, Fernández-Pozo, L., Loures, L. and Kurowska-Pysz, J. (2019), Political commitment and transparency as a critical factor to achieve territorial cohesion and sustainable growth. European cross-border projects and strategies, Regional Science Policy \& Practice, 11(2), pp. 423-435. https://doi.org/10.1111/rsp3.12201

Chaban, N., Elgström, O., Kelly, S. and Yi, L.S. (2013), Images of the EU beyond its borders: Issue-specific and regional perceptions of European Union power and leadership, Journal of Common Market Studies, 51(3), pp. 433-51. https://doi.org/10.1111/jcms.12004

Elgström, O. and Chaban, N. (2015), 'Studying External Perceptions of the EU: Conceptual and Methodological Approaches' in: Bachmann, V. and Muller, M. (Eds.), Perceptions of the EU in Eastern Europe and Sub-Saharan Africa. Looking in from the Outside (Europe in a Global Context), pp. 17-33, London: Palgrave Macmillan.

European Commission (2011), Joint Communication to the European Parliament, The Council, The European Economic and Social Committee and the Committee of the Regions: A new response to a changing Neighbourhood, (retrieved from https://eurlex.europa.eu/legal-content/EN/TXT/?uri=celex\%3A52011DC0303).

European Commission (2012), Communication from the commission to the European parliament and the council the EU approach to resilience: learning from food security crises, (retrieved from https://ec.europa.eu/europeaid/eu-approach-resilience-learningfood-security-crises-com2012-586_en).

European Commission (2013), Action Plan for Resilience in Crisis Prone Countries 2013-2020 (retrieved from https://ec.europa.eu/echo/files/policies/resilience/com_2013_227 _ap_crisis_prone_countries_en.pdf).

European Commission (2014), Joint Communication to the European Parliament, the European Economic Council, Social Committee and the Committee Of The Regions, Neighbourhood at the Crossroads: Implementation of the European Neighbourhood Policy in 2013 (retrieved from http://eeas.europa.eu/enp/pdf/2014/joint_ communication_en.pdf).

European Commission (2017), European Commission \& High Representative of the Union for Foreign Affairs and Security Policy "Joint Communication to the European Parliament and the Council - The resilience approach in EU's external action”, (retrieved from: https://eeas.europa.eu/sites/eeas/files/join_2017_21_f1_communication_from_commis sion_to_inst_en_v7_p1_916039.pdf).

European Commission (2018a), For a more competitive and innovative European financial sector, (retrieved from: https://eur-lex.europa.eu/resource.html?uri=cellar: 6793c578-22e6-11e8-ac73-01aa75ed71a1.0001.02/DOC_1\&format=PDF).

European Commission (2018b), Annual report 2018 On the implementation of the European Union's instruments for financing external actions in 2017 (retrieved from: https://ec.europa.eu/europeaid/sites/devco/files/annual-report-2018-hres20190212_en.pdf). 
European Commission (2020), EU financial support to Ukraine and Moldova, (retrieved from: https://ec.europa.eu/neighbourhood-enlargement/neighbourhood/countries/ ukraine_en).

European Council (2018), A new strategic agenda 2019 - 2024 (retrieved from https://www.consilium.europa.eu/media/39914/a-new-strategic-agenda-2019-2024.pdf).

European Migration Network (2019), Impact of visa liberalisation on countries of destination - synthesis report, Brussels: European Migration Network.

European Union Global Strategy (EUGS) (2016), Shared vision, common action: A stronger Europe. A Global Strategy for the European Union's Foreign and Security Policy, June 2016 (retrieved from https://europa.eu/globalstrategy/sites/globalstrategy/ files/eugs_review_web.pdf).

Garmezy, N. (1971), Vulnerability Research and the Issue of Primary Prevention, American Journal of Orthopsychiatry, 41(1), pp. 101-116. https://doi.org/10.1111/j.19390025.1971.tb01111.x

Geyer, H.S. (2006), The changing global economic landscape, in: Geyer, H.S. (Ed.), Global regionalization: Core peripheral trends, Cheltenham/Northampton: Edward Elgar, pp. 67-86.

Gideon, L. (2012), Handbook of survey methodology for the social sciences, New York: Springer. https://doi.org/10.1007/978-1-4614-3876-2

Hallegatte, S., Vogt-Schilb, A.C., Bangalore, M. and Rozenberg, J. (2016), Unbreakable: building the resilience of the poor in the face of natural disasters, World Bank Group. https://doi.org/10.1596/978-1-4648-1003-9

Haukkala, H. and Medvedev, S. (eds.), (2001), The EU Common Strategy on Russia: Learning the Grammar of the CFSP (Kauhava: Ulkopoliittinen instituutti and Institut für Europäische Politik, 2001).

Hill, C. (1993), The capability-expectations gap or conceptualizing Europe's international role, Journal of Common Market Studies, 31(3), pp. 305-28. https://doi.org/10.1111/j.14685965.1993.tb00466.x

Holland, M. and Chaban, N. (2014), Communicating Europe in times of crisis: External perceptions of the European Union, Basinkstoke: Palgrave Macmillan. https://doi.org/10.1057/9781137331175

Incaltarau, C., Sharipov, I., Pascariu, G.C. and Moga, T.L. (2021), Growth and convergence in Eastern Partnership and Central Asian countries since the dissolution of the USSRembarking on different development paths?, Development Policy Review. https://doi.org/10.1111/dpr.12547

JDR (2015), Joint Declaration of the Eastern Partnership Summit (retrieved from https://www.consilium.europa.eu/media/21526/riga-declaration-220515-final.pdf).

JOIN (2013), European Commission, Joint Communication to the European Parliament, the Council, the European Economic and Social Committee and the Committee of the Regions: European Neighbourhood Policy: Working towards a Stronger Partnership, Brussels, 20.3.2013, (retrieved from https://library.euneighbours.eu/ content/european-neighbourhood-policy-working-towards-stronger-partnership). 
JOIN, (2017), 21 Joint Communication to the European Parliament and the Council A Strategic Approach to Resilience in the EU's external action, Brussels, 7.6.2017, (retrieved from https://ec.europa.eu/knowledge4policy/publication/2017-jointcommunication-strategic-approach-resilience-eus-external-action_en).

JRC (2017), Joint Research Centre - JRC Science for Policy Report: Building a Scientific Narrative Towards a More Resilient EU Society (retrieved from: https://publications.jrc.ec.europa.eu/repository/bitstream/JRC106265/jrc106265_1004 17_resilience_scienceforpolicyreport.pdf).

Juncos, A.E. (2016), Resilience as the new EU foreign policy paradigm: a pragmatist turn?, European Security, 26(1), pp. 1-18. https://doi.org/10.1080/09662839. $\underline{2016.1247809}$

Korosteleva, E. (2010), Moldova's European Choice: 'Between Two Stools'?, European-Asia Studies, 62(8), pp. 1267-1289. https://doi.org/10.1080/09668136.2010.504383

Korosteleva, E. (2018), Paradigmatic or Critical? Resilience as a New Turn in EU Governance for the Neighbourhood, Journal of International Relations and Development. https://doi.org/10.1057/s41268-018-0155-Z

Korosteleva, E. (2019), Reclaiming resilience back: A local turn in EU external governance, Contemporary Security Policy, 41(2), pp. 1-34. https://doi.org/10.1080/13523260.2019.1685316

Korosteleva, E. and Flockhart, T. (2020), Resilience in EU and international institutions: Redefining local ownership in a new global governance agenda, Contemporary Security Policy, 41(2), pp. 153-175. $\quad$ https://dx.doi.org/10.1080/13523260. 2020.1723973

Ledogar, R.J. and Fleming, J. (2008), Social Capital and Resilience: A Review of Concepts and Selected Literature Relevant to Aboriginal Youth Resilience Research (retrieved from https://www.ncbi.nlm.nih.gov/pmc/articles/PMC2956751/).

Lucarelli, S. (2013), Perceptions of the EU in international institutions, in: Jørgensen, K.E. and Laatikainen, K.V. (Eds.), Routledge Handbook on the European Union and International Institutions, pp. 429-444. Abingdon: Routledge.

Manea, G.M. (2017), Effective Development and Resilience Building: the EU and NATO perspectives compared, CES Working Papers, IX, 3(20).

Manners, I. (2002), Normative power Europe: A contradiction in terms?, Journal of Common Market Studies, 40(2), pp. 235-58. https://doi.org/10.1111/1468-5965.00353

Mitchell, A. (2013), Risk and Resilience from Good Idea to Good Practice, A Scoping Study for the Experts Group on Risk and Resilience, Paris: OECD.

OECD (2013), Government at a glance (retrieved from https://www.oecdilibrary.org/docserver/gov_glance-20136en.pdf?expires=1598125705\&id=id\& accname $=$ guest\&checksum=AFC13ADB2648A746681BFDD9978946EC).

OECD (2017), Trust and Public Policy: How Better Governance Can Help Rebuild Public Trust, OECD Public Governance Reviews, OECD Publishing, Paris. https://doi.org/10.1787/9789264268920-en 
Pascariu, G.C., Simionov, L.M., and Incaltarau, C. (2020), Resilience - an emerging paradigm in EU's external action', in: Duarte, A., Simões, M., Bação, P. and Martins, R. (eds.), Estudos de Homenagem a João Sousa Andrade, Coimbra: Almedina, pp. 253-273.

Petrova, I. and Delcour, L. (2020), L. From principle to practice? The resilience-local ownership nexus in the EU Eastern Partnership policy, Contemporary Security Policy, 41(2), pp. 336-360. https://doi.org/10.1080/13523260.2019.1678280

Prokkola, E.K. (2019), Border-regional resilience in EU internal and external border areas in Finland, European Planning Studies, 27(8), pp. 1587-1606. https://doi.org/10.1080/09654313.2019.1595531

Samokhvalov, V. (2015), Ukraine between Russia and the European Union: Triangle Revisited, $\begin{array}{llll}\text { Europe-Asia } \quad \text { Studies, } & \text { 67(9), 1371-1393. }\end{array}$ https://doi.org/10.1080/09668136.2015.1088513

Schimmelfennig, F. (2008), EU political accession conditionality after the 2004 enlargement: consistency and effectiveness, Journal of European Public Policy, 15(6), pp. 918-937. https://doi.org/10.1080/13501760802196861

Schimmelfennig, F. (2010), The normative origins of democracy in the European Union: Toward a transformationalist theory of democratization, European Political Science Review, 2(2), pp. 211 - 233. https://doi.org/10.1017/S1755773910000068

Simionov, L.M. (2020), European Union's pursuit of resilience in the Eastern Neighbourhood, CES Working Papers, 12(4), pp. 257-266.

Simionov, L.M. and Tiganasu, R. (2018), Historical incrementalism and its effects on the (mis) perception of liberalism in Russia. Guidance from in-country experts, Europolity, 12(2), pp. 35-150.

Smith, M. E. (2010) Negotiating New Europe: The roles of the European Union, Journal of European Public Policy, 7(5), pp. 806-822. $\underline{\text { https://doi.org/10.1080/ }}$ 13501760010014966

Tocci, N. (2019), Resilience and the role of the European Union in the world, Contemporary Security Policy, 41(2), pp. 1-19. https://doi.org/10.1080/13523260.2019.1640342

Valiyeva, K. (2016), The EU's Eastern Partnership: normative or geopolitical power projection?, Eastern Journal of European Studies, 7(2), pp. 11-29.

Vogler, J. and Bretherton. C. (2006), The European Union as a protagonist to the United States on climate change, International Studies Perspectives, 7(1), pp. 1-22. https://doi.org/10.1111/j.1528-3577.2006.00225.x

Wagner, W. and Anholt, R. (2016), Resilience as the EU Global Strategy's new leitmotif: pragmatic, problematic or promising?, Contemporary Security Policy, 37(3), pp. 413430. https://doi.org/10.1080/13523260.2016.1228034

Windle. G. (2010), What is resilience? A review and concept analysis, Reviews in Clinical Gerontology, 21(2), pp. 152-169. https://doi.org/10.1017/S0959259810000420 